\title{
Speaking for Bakhtin: Two Interpretations of Reported Speech A Response to Goddard and Wierzbicka (2018)
}

\author{
Stef Spronck \\ University of Helsinki \\ PL 24 (Unioninkatu 40) Helsinki, 00014, Finland
}

\begin{abstract}
Vološinov ([1929]1973) is one of the most frequently cited works in studies on reported speech, but its interpretation varies considerably between authors. Within the linguistic anthropological tradition, its central message is often conflated with Erving Goffman's 'speaker roles', and in a recent publication, Goddard and Wierzbicka (2018) marry ideas they attribute to Vološinov (1973) and Mikhail M. Bakhtin to those by the formal semanticist Donald Davidson. Responding to Goddard and Wierzbicka (2018) (and a shorter version of a similar argument in Goddard and Wierzbicka (2019), this paper seeks to explore the philosophical foundations of reported speech research, particularly in relation to Vološinov/Bakhtin. It suggests that reported speech research is motivated by two fundamentally distinct goals, one here labelled 'Fregean' and the other 'Bakhtinian'. Questions and methods used in both of these research traditions lead to two radically different understandings of reported speech. This affects the applicability of the definition of direct/indirect speech Goddard and Wierzbicka (2018) propose. It also motivates an alternative approach to reported speech advocated by the current author and others that is criticised by Goddard and Wierzbicka (2018). The article further seeks to rehabilitate the analysis of Wierzbicka (1974), which Goddard and Wierzbicka (2018) partially reject. Whereas Wierzbicka (1974) treats direct and indirect speech as constructions of English, Goddard and Wierzbicka (2018) elevate the opposition to a universal, which belies the cultural sensitivity to semantic variation the authors display in other work. The paper concludes with a brief note about the semantic status of 'say' in Australian languages and states that the relevance of Vološinov ([1929]1973) is undiminished, also in the light of recent developments in language description. It remains a highly original study whose implications are yet to fully impact research on reported speech.
\end{abstract}

Keywords: reported speech, dialogism, Valentin N. Vološinov; Mikhail M. Bakhtin; Gottlob Frege; Australian aboriginal languages (Ungarinyin)

\section{For citation:}

Spronck, Stef (2019). Speaking for Bakhtin: Two Interpretations of Reported Speech. A Response to Goddard and Wierzbicka (2018). Russian Journal of Linguistics, 23 (3), 603-618. doi: 10.22363/2312-9182-2019-23-3-603-618. 


\title{
Говорить устами Бахтина: две интерпретации косвенной речи (ответ К. Годдарду и А. Вежбицкой [2018])

\author{
Стеф Спронк
} \\ Хельсинский университет \\ PL 24 (Unioninkatu 40) Хельсинки, 00014, Финляндия
}

\begin{abstract}
Аннотация
Работа В. Н. Волошинова (Vološinov, 1929/1973) — один из наиболее цитируемых научных трудов, посвященных косвенной речи, однако его интерпретация разными авторами неоднозначна. В рамках лингвоантропологической традиции его основной посыл часто смешивается с «ролями говорящего» Э. Гоффмана, а в своей недавней публикации К. Годдард и А. Вежбицкая (2018) объединяют идеи, которые они приписывают В. Н. Волошинову и М. М. Бахтину, с идеями представителя формальной семантики Д. Дэвидсона. Настоящая статья - это ответ Годдарду и Вежбицкой (2018), в ней рассматриваются философские основы исследования косвенной речи, особенно по отношению к идеям Волошинова / Бахтина. Высказывается мысль о том, что изучение косвенной речи преследует две основные цели, одна из которых восходит к Фреге, а вторая - к Бахтину. Вопросы и методы, связанные с этими традициями, ведут к двум радикально различным пониманиям косвенной речи. Это влияет на применимость определения прямой / непрямой речи, предлагаемого Годдардом и Вежбицкой, а также порождает альтернативный подход, развиваемый автором данной статьи и другими учеными и критикуемый Годдардом и Вежбицкой (Там же). Цель статьи - реабилитировать анализ Вежбицкой (1974), от которого Годдард и Вежбицкая (2018) частично отказываются. Рассматривая прямую и непрямую речь как английские конструкты, они, тем не менее, поднимают это понятие до универсального уровня, что вступает в противоречие с понятием культурной сенситивности относительно семантических вариаций, о котором они пишут в других работах. Автор статьи приходит к выводу, что, в свете современных тенденций описания языка, труд Волошинова (1929/1973) не теряет свой значимости и заслуживает всяческого внимания.
\end{abstract}

Ключевые слова: передача чужой речи, диалогизм, В.Н. Волошинов, М.М. Бахтин, Г. Фреге, языки аборигенов Австралии (Ungarinyin)

\section{Для цитирования:}

Spronck, Stef (2019). Speaking for Bakhtin: Two Interpretations of Reported Speech. A Response to Goddard and Wierzbicka (2018). Russian Journal of Linguistics, 23 (3), 603-618. doi: 10.22363/2312-9182-2019-23-3-603-618.

\section{Introduction: Reported speech and the direct/indirect speech opposition}

The study of reported speech, the linguistic structures and meanings involved in talking about an utterance, centres around two broad questions: how do expressions of reported speech relate to non-reported speech expressions, and what are the relevant semantic and structural oppositions among expressions of reported speech? The implications of how we answer these questions are surprisingly far-reaching.

With respect to the question of how to distinguish between reported speech constructions, the analysis of direct speech, as in (1), and indirect speech (also: direct/indirect discourse), as in (2) has become a standard.

(1) John said: I am a fool.

(2) John said that he was a fool. (Wierzbicka 1974, 267) 
Wierzbicka (1974) demonstrates that, contrary to traditional accounts in Transformational Generative Grammar, constructions as in (2) are not simply derived from those in (1). Rather, the distinction between the two constructions rests in the semantic effect the current speaker intends to achieve.

"I submit that the "illocutionary purpose" [(i.e. the real or pretended intention with which the speech act is performed, as indicated by the speaker] of the semidirect discourse, is roughly this:

I want to cause you to know what this person said, whereas that of direct discourse is double:

I want to cause you to know what this person said, I want to cause you to know how he said it.' (Wierzbicka 1974, 274-75)

In other words, with a construction as in (2), the speaker simply signals that John thinks of himself as a fool, whereas in (1) a further communicative intention is to signal that John used the very words of the reported speech clause to convey this message. In summary:

'in direct quotation one assumes the role of the original speaker, i.e. one imagines oneself as that original speaker; in indirect speech one undertakes to state the content of the speech as though one were prepared to assert it oneself' (Wierzbicka 1974, 284-85).

The broader question of how reported speech, exemplified by direct and indirect speech clauses, relates to other linguistic expressions has deep roots in the philosophy of language. Wierzbicka (1974), and, more recently, Goddard and Wierzbicka (2018), critically engage with this philosophical literature, particularly by responding to the work of Donald Davidson (1968) and Mikhail Bakhtin/Valentin Vološinov (1973). They explicitly present their definitions of direct and indirect speech as an alternative to a definition proposed in Spronck (2015a), which was developed further in Spronck (2017) and Spronck and Nikitina (2019).

In the present paper I aim to pursue three goals: (1) I want to voice opposition to parts of the analysis in Goddard and Wierzbicka (2018), and Goddard and Wierzbicka (2019) ${ }^{1}$, in favour of the account in Wierzbicka (1974); (2) I want to highlight the distinctions between the approaches to reported speech by Davidson (1968) and Vološinov (1973), and position Goddard and Wierzbicka (2018) with respect to the research goals of these two authors; and (3) I want to address Goddard and Wierzbicka's (2018) claim that the distinction between direct and indirect speech forms a universal category. The discussion motivates the need I perceive for an alternative to the lexical approach Goddard and Wierzbicka (2018) advocate.

${ }^{1}$ Goddard and Wierzbicka (2019) cover much of the same ground as Goddard and Wierzbicka (2018). The current paper is primarily a response to the longer, earlier paper but may also be read as a reply to Goddard and Wierzbicka (2019) where points are addressed that are relevant to both Goddard and Wierzbicka (2018) and Goddard and Wierzbicka (2019). 
Section 2 begins by sketching the philosophical foundations of reported speech research, as represented by Frege (1892) and authors such as Davidson (1968) on the one hand, which I label the Fregean tradition (section 2.1). A separate approach is formed by Vološinov (1973), the Bakhtinian tradition (section 2.2). My main aim is to demonstrate that the uniqueness of the Bakhtinian position is consistently downplayed in the literature, and that Goddard and Wierzbicka (2018) and Goddard and Wierzbicka (2019) are no exception. In section $2.3 \mathrm{I}$ argue that the approach in Goddard and Wierzbicka (2018) is primarily Fregean (and more so than the approach in Wierzbicka (1974)). My main point is that while Goddard and Wierzbicka (2018) purport to speak for the Bakhtinian position, their concern is mostly with the Fregean objective of qualifying the relation between the words used in reported speech and the world, whereas the Bakhtinian account is about how the form of a reported speech expression may reflect complex social relations between the current speaker, the addressee and the reported speaker. These philosophical affiliations are fundamental to appreciating the relative role of language structure and meaning in the analysis of reported speech, which lies at the heart of the debate about direct/indirect speech. For the Fregean approach and Goddard and Wierzbicka (2018) this opposition is a binary distinction between saying something about the words of a reported speaker (direct speech) and saying something about what the reported speaker means (indirect speech). For the Bakhtinian approach the distinction between direct and indirect speech is relevant for an entirely different reason. Bakhtin states that what we say is always influenced by the words of others in some way, but in reported speech these 'other voices' actually become overt through the syntactic construction of the utterance. Direct and indirect speech (and the many intermediate strategies languages may have) are different structural ways of explicitly making other voices heard. From the Bakhtinian perspective, the opposition between direct and indirect speech is only relevant in the sense that it illustrates how the speaker can structurally signal other voices: direct speech displays the voice of the reported speaker as if the current, reporting speaker reflects it fully (cf. also Wierzbicka 1974), 'less direct' strategies increasingly signal that the voice of the reported speaker is filtered through that of the reporting speaker.

Section 3 takes up the claim that, as per Goddard and Wierzbicka (2018), direct/ indirect speech are universal categories. It discusses the Australian Aboriginal language Ungarinyin, for which Rumsey (1990) claims the opposition between direct and indirect speech is not structurally relevant (also see McGregor 2014) and demonstrates that the verb 'say' and the syntactic construction used to express reported speech are separate linguistic units. I argue that the observations by Rumsey (1990) and McGregor (2014) do not invalidate the proposal that 'say' and 'think' are universal concepts, but strongly suggest that reported speech constructions and the lexemes 'say' and 'think' are not necessarily related. This idea is not addressed by Goddard and Wierzbicka (2018, 2019), or Knight (2008), on whose analysis they rely for the Australian language Bunuba. Section 4, finally, forms a brief discussion and conclusion. 


\section{Philosophical foundations: reported speech as a problem of reference, and as grammar of dialogue \\ 2.1. Frege (1892) and his discontents}

The most prominent introduction of reported speech/quotation ${ }^{2}$ in the Western philosophy of language and formal semantics is formed by the following passages from Frege's (1892) Sinn und Bedeutung:

'In reported speech one talks about the sense - e.g., of another person's remarks. It is quite clear that in this way of speaking words do not have their customary referents but designate what is usually their sense. In order to have a short expression, we will say: In reported speech, words are used indirectly or have their indirect referents. [...] Such exceptions must always be borne in mind if the mode of connection between sign, sense, and referent in particular cases is to be correctly understood (Frege 1948, 211-12) [...] '[T] he truth value of a sentence containing another as part must remain unchanged when the part is replaced by another sentence having the same truth value. Exceptions are to be expected when the whole sentence or its part is direct or indirect quotation [...]. In direct quotation, a sentence designates another sentence, and in indirect quotation a thought. [...] [In] indirect quotation [...] the words [...] have their indirect referents coinciding with what is customarily their sense (Frege 1948, 218)

There is much to unpack in these statements, and formal semantic/pragmatic approaches to reported speech continue to do so until the present day. However, the basic idea is relatively simple: 'regular' linguistic signs have a direct referential relationship with the real world, but reported speech does not. For Frege (1892), reported speech on the one hand presents an interesting anomaly, but is also the exception that confirms the rule: it enforces the relevance of drawing a distinction between abstract 'sense' and referential meaning. Reported speech does not have a denotational/referential meaning in the here-and-now (i.e. it is 'used indirectly'), which shows that the semantics of an element are more general than the specific instantiation of $i^{3}$.

This distinction gave rise to the often invoked opposition between 'using words' (i.e. invoking reference in the here-and-now of the speech situation) and 'mentioning words' (i.e. using words not to directly refer) (Goddard and Routley 1966; Saka 1998; Saka 2006, 455; also see Burge 2012; Jacquette 2017 for useful literature reviews). Quine (1956) is the first author to discuss this distinction using the labels de dicto and de re. With a de dicto 'about the speech' interpretation, the addressee understands the wording of the reported utterance (henceforth: $\mathrm{R}$ ) to reflect the form of the message

2 The most common term used within the logical tradition is 'quotation', which, depending on the author may either refer to direct speech only, direct speech-like phenomena (e.g. mentioning a book title), the opposition between direct and indirect speech or an even broader interpretation closer to reported speech in the sense of Vološinov (1973). Here, I will use quotation/reported speech interchangeably. I do not adopt 'represented speech', a third term that is commonly found in the literature, but my interpretation of 'reported speech' is synonymous with the way in which, e.g. Banfield (1982) uses the latter notion. Also note that reported speech constructions frequently express types of mental processes other than speech, such as thought or intention. Güldemann $(2008,5)$ adopts the label 'reported discourse' for this reason.

3 'Denotation' is a more appropriate term to represent the Fregean position than 'reference' (Capuano 2012), but given the centrality of referential meaning to much of the subsequent discussion on reported speech/quotation, which Frege (1892) foreshadows, I will mostly use the latter term here. 
in the projected reported speech situation. Under a de re 'about the thing' interpretation, $\mathrm{R}$ is understood as an utterance describing the contents of projected reported utterance (i.e. presenting what it was about, rather than implying that the reporting utterance represents the reported message 'accurately'). Indirect speech commonly allows for both readings, whereas the de re reading is unavailable for direct speech constructions, they always 'mention' $\mathrm{R}$ and are therefore not just about what $\mathrm{R}$ means but also about how $R$ is formulated.

The opposition between direct and indirect speech, illustrated in (1) - (2), remains a fixture of formal semantic/pragmatic research. However, the exact boundaries between de dicto/de re interpretations are difficult to draw (Goddard and Routley 1966) and the distinction is controversial (cf. Cieśluk 2010; Cappelen and Lepore 2012). One reason for this is, as Saka (1998) points out, that a word can be 'mentioned' in relation to multiple properties, highlighting, e.g., the phonological, conceptual or lexical form(s) of R. Given that the de dicto/de re interpretations covary, but not always perfectly correlate with the structural expression of reported speech, formal semantic and formal pragmatic authors have come to distinguish a range of sub-types of reported speech/ quotation, such as 'open quotation' (Recanati 2001, 2008), 'hybrid quotation' (De Brabanter 2005), 'mixed quotation' (Geurts and Maier 2005; Maier 2007) and 'double-duty quotation' (García-Carpintero 2011).

Within this broad research tradition, which I here label 'Fregean', authors differ about whether reported speech is a semantic or primarily a pragmatic phenomenon (Recanati 2001; Gutzmann and Stei 2011; De Brabanter 2017), about the status of the reported clause (Abbott 2011,35), and about what other types of phenomena count as 'mentioning' words (see Saka 2006) for an interesting discussion of positions). What this literature largely agrees on, however, is that Frege (1892) indeed correctly identifies why reported speech presents a problem for linguistic analysis: it atypically does not allows speakers to say something about the world, but can receive de dicto interpretations. It can be about how words are said.

\subsection{Vološinov/Bakhtin and dialogism}

Vološinov (1973) originates a second tradition of reported speech research. Formal semantic and formal pragmatic authors adopting and revising Frege's (1892) account rarely reference Vološinov (1973), but the work has become influential in descriptive and linguistic anthropological studies. Often however, references to Vološinov (1973) primarily serve to establish reported speech as a historically accepted research topic, standing in a similar sociological tradition as later developed by Goffman $(1979,1981)^{4}$.

${ }^{4}$ Goodwin $(2007,29)$ states that he was 'urged [...] to read Volo[š]inov (1973)' by his teacher Erving Goffman, while the latter was working on Goffman (1979), and suggests that 'Goffman's thinking in [Goffman (1979)] was influenced in part by his reading of Volo[š]inov', although Goodwin $(2007,29)$ also notes to 'have no other evidence', since Vološinov (1973) is not cited in Goffman (1979) and cited only once in Goffman (1981). The Vološinovian/Bakhtinian notions of 'voice' and the Goffmanian notion of 'footing' are often described as approximate equivalents (e.g. Kuipers 2013, 401) (although see Cresswell and Hawn 2011). Discussing the notion of addressivity, Bertau (2004, 122) credits Bakhtin with introducing the idea that all language is 'addressed' on some level, and then refers to Goffman and Levinson as taking this idea further, by delimiting addressivity to participation, and by specifying types of participation in face-to-face interaction. The impression that emerges 
Goddard and Wierzbicka (2018) dilute the unique contribution of Vološinov (1973) even further, by insisting that their account both draws on this work ${ }^{5}$ and on the formal semanticist Davidson (1968), suggesting that the two address similar questions.

This is a mistake. In order to demonstrate how Goddard and Wierzbicka (2018) misrepresent Vološinov (1973), it is important to understand the context in which the study of reported speech appears in Vološinov (1973), a volume about how social relations affect language. The study constitutes the last section of the book, and is entitled $K$ istorii form vyskazyvanija $v$ konstrukcijax jazyka 'On the history of the forms of the utterance in linguistic constructions' (emphasis added) ${ }^{6}$, starting with a chapter called Teorija vyskazyvanija i problemy sintaksisa 'The theory of the utterance and problems of syntax' (emphasis added). The key points listed at the head of this chapter include: Značenie problemy sintaksisa 'The meaning (or: significance) of problems of syntax', Sintaksičeskie kategorii i vyskazyvanie kak celoe 'Syntactic categories and the utterance as a whole' and Problema form peredači čužoj reč $i$ 'The problem of the forms of transmission of reported speech' (emphasis added). In the little more than nine pages of the second chapter of this book section, Èkspozicija problemy «čužoj reči 'Exposition of the problem of reported speech (lit.: 'another speech')', the word sintaksis 'syntax' occurs eight times and form 29 times, as opposed to, e.g., smysl or značenie 'meaning' (or derivations of the words), which occur nine times and once, respectively (but not in relation to the semantics of reported speech).

Nevertheless, Goddard and Wierzbicka (2018) remark, without any additional argumentation:

'It seems clear to us that for Bakhtin himself the grammatical mechanisms involved were not the main point: to be sure, they needed to be understood, but only as a means to an end; and the end had to do not with grammar as such, but with meaning.'

Not only does this statement ignore the extensive signposting in Vološinov (1973), but it explicitly goes against the central message of the study: the meaning of reported speech is exactly not what makes the phenomenon particularly interesting for Vološinov/ Bakhtin's purposes ${ }^{7}$.

from these, admittedly rather random, observations about the reception of Vološinov (1973), is that Goffman (1981), and, in extension, ethno-methodologically based accounts in linguistic anthropology and Interactional Linguistics have superseded the proposal in Vološinov (1973).

5 Goddard and Wierzbicka (2018) consistently refer to the author of Vološinov (1973) as 'Bakhtin'. Although there is no doubt that Valentin Vološinov and Mikhail Bakhtin were close collaborators, the assumption from the 1980s that Mikhail Bakhtin is the author of Vološinov (1973) is no longer commonly stated as fact, and is rejected by most Bakhtin scholars (Bota and Bronckart (2011) even denounce the idea as a collective delusion, maliciously fuelled by Bakhtin himself). For a comprehensive overview of positions in the debate about the question of authorship, in favour of assuming Bakhtin, Vološinov or both as (primary) authors of this work, see Lähteenmäki (2001, 16ff.). Also see Erdinast-Vulcan and Sandler (2015) for an authoritative discussion of current thinking about Bakhtin's philosophical school.

6 Subtitle: Opyt primenenija sociologicheskogo metoda k problemam sintaksisa 'An essay applying a sociological method to the problems of syntax' (emphasis added).

7 Vološinov (1972) writes: čužoe vyskazyvanie javljaetsja ne tol'ko temoj reči " 'A reported utterance, however, is not just a theme [content] of speech' (Vološinov 1973, 115). 
What are these purposes? Studying language as dialogue, or 'Dialogism', the term later given to the conceptualisation of language and human interaction in the sense of both Vološinov (1973) and Bakhtin (Holquist 2002; Erdinast-Vulcan and Sandler 2015). The fundamental idea of Dialogism is that all actions and utterances are inherently interactive. They respond to and anticipate other actions and utterances and are therefore always shaped by (imagined) dialogue. The loudness, the register, the length, and even the meaning of what I say is shaped by how I expect you to receive it, and how you have talked to me in the past. Nothing in the dialogic conceptualisation of language is ever exempt from being intersubjective or interpersonal.

In this respect, a direct speech sentence, as in (1), is no different from any other utterance. For example, if I say "Ponyo is surely better than Totoro," I expect you not only to be able to identify the name of Studio Ghibli anime films (and even to understand the abbreviated title 'Totoro'), but to have an opinion about them and share the opinion that the first title is better than the second. For Vološinov (1973) and Bakhtin all of these expectations are part of the meaning of this utterance, and if we would want to quantify these dialogic meanings (can you identify these referents, is this a topic I can discuss with you, do you share my attitude?) the sentence above perhaps contains even more interpersonal meanings than any common utterance of direct speech. What makes the direct speech construction (1) different is that we can actually see that this sentence has a dialogic nature, because it has the form of a dialogic exchange. In the famous phrase of Vološinov (1973): 'what is expressed in the forms employed for reporting speech is an active relation of one message to another, and it is expressed, moreover, not on the level of the theme but in the stabilized constructional patterns of the language itself' (Vološinov 1973, 116, italics in the original).

Calling Bakhtin's account of reported speech 'interpersonal' is similar to saying, e.g., "for Newton, an apple has gravity". The point is not that reported speech is somehow special in having dialogic qualities - for Bakhtin and Vološinov everything does. Reported speech is salient because it demonstrates its dialogic nature in a way that allows us to study it with relatively conventional linguistic means, as a linguistic form. Like Newtons anecdotal apple, reported speech is a symptom, it represents an instance of a much broader phenomenon, viz. the principle of Dialogism, but reported speech constructions allow us to recognise this phenomenon.

This is where the Bakhtinian approach to reported speech is truly unique. Vološinov (1973) does not come to the topic because it conflicts with a core idea of how he believes language should work, it follows from this idea. Frege (and the authors who subsequently followed or contested his views, as described in the previous section) see reported speech/quotation as a problem for explaining language as a referential phenomenon, an apparent exception to the idea that language consists of a relation between a meaning and some referential value in the external world. For Vološinov (1973)/Bakhtin reported speech affirms their view of language as dialogue: it shows that dialogue as the fundamental organising principle in language can even be studied in syntax.

This means that Vološinov (1973) assigns the distinction between direct and indirect speech a radically different interpretation: '[the forms used in reported speech] reflect basic and constant tendencies in the active reception of other speakers' speech' (Vološi- 
nov 1973, 117). In direct speech, the reported message $\mathrm{R}$ retains maximum 'constructional and semantic autonomy' (Vološinov 1973, 115), structurally showing that the current speaker steps out her own speech and adopts the dialogic role of the reported speaker. In indirect speech as in (2), on the other hand, $\mathrm{R}$ is structurally embedded, reflecting a perceiving, rather than a reproducing role on behalf of the current speaker:

"Indirect discourse "hears" a message differently; it actively receives and brings to bear in transmission different factors, different aspects of the message than do the other patterns' (Vološinov 1973, 129).

Here, Vološinov (1973) comes close to a version of the de dicto/de re distinction the pro- and anti-Fregeans take as a binary opposition ${ }^{8}$. But the Bakhtinian goal is not to diagnose the difference between 'mentioning' vs. 'using' words, but to explain this distinction. Direct speech is inherently de dicto because, as a structural representation of dialogue, it aims to represent the position of the reported speaker. Indirect speech can be interpreted as de re because, as a structural representation of dialogue, it aims to represent the position of the perceiving, current speaker. Thereby, the subtle 'syntactic, stylistic and compositional norms' (Vološinov 1973, 116) used in reported speech constructions, 'in the stabilized constructional patterns of the language itself' (Vološinov 1973, 116), provide a unique opportunity for studying the way in which speakers evaluate and transmit the words and ideas of others in grammar. Despite the abundant references to Vološinov (1973) and Bakhtin in the literature on reported speech, I would say that this is a challenge that we still barely have begun to explore.

\subsection{Positioning Wierzbicka (1974) and Goddard and Wierzbicka (2018) among the Fregean and Bakhtinian traditions}

How do the definitions of direct and indirect speech Goddard and Wierzbicka (2018) propose relate to the traditions sketched above? Let us first consider their main generalisations about direct speech $^{9}$ :

(3) 'In all parts of the earth, often something like this happens:

Someone says some things to someone else.

After some time, this someone else wants some other people to know what this someone said/

At the same time this someone else wants these other people to know how this someone said it. Because of this, this someone else says two things, one after the other: one is "this someone said/spoke like this ..."

the other one is the same thing as this someone said

when this someone else says it, he/she wants to say it in the same way, with the same words. If one of these words was "I", this someone else says it with the word "I". If this someone said it with words like "now", "here", "this", this other someone says it with the same words' (Goddard and Wierzbicka 2018)

\footnotetext{
${ }^{8}$ Sergeiy Sandler (p.c.) rightly points out that since the mixing of voices in reported speech cannot be captured in a binary opposition with Bakhtin/Vološinov's approach, characterising it in terms of the Fregean distinction de dicto/de re is not satisfactory (cf. Sandler 2013, 2016).

9 Goddard and Wierzbicka (2018) introduce two 'similar-but-different' versions of the generalisation in (3), only one of which is cited here. The objections to this representation put forward in this section apply to both.
} 
The central part of the definition in (3) serves to explicate de dicto interpretation: each component in (3a), (3b) and (3c) restates an aspect of de dicto in increasingly specific terms, viz. it reflects how $\mathrm{R}$ is to be interpreted, that it (purportedly) uses the 'same words' as the reported speaker, and gives examples of deictic words. Goddard and Wierzbicka (2018) acknowledge their philosophical affiliation with the early sketch of the demonstrative theory in Davidson (1968), but also reject Davidson's approach, because of his claim that in direct speech the current, reporting speaker acts as a "samesayer" of the reported speaker (i.e. actually says what the reported speaker said, rather than just say it in the same way). According to them, Wierzbicka (1974) 'essentially agreed with Davidson on this point'. Puzzlingly, however, Wierzbicka (1974) does not:

'The semantic representation proposed by Davidson [for the sentence 'Galileo said: "The earth moves"'] is this:

The earth moves.

$(\exists x)$ (Galileo's utterance $x$ and my last utterance make us samesayers).

In my opinion, Davidson's analysis needs one correction: the person reporting Galileo's sentence does not really represent himself as Galileo's samesayer, because he does not commit himself to Galileo's view; he only behaves as though he wanted to be Galileo's samesayer, warning his addressee at the same time that this behaviour is just acting. The reporter imagines that he wants to be Galileo's samesayer [...], and he behaves accordingly - all with the purpose of letting the addressee know what Galileo said [...]. He does not make the same assertion that Galileo did.' (Wierzbicka 1974, 286-87, emphasis added)

In other words, the reporting speaker does not actually say what the reported speaker said; direct speech allows the current speaker to behave as if she did. This 'dramatic' or 'performative' quality was one of the main insights Wierzbicka (1974) added to the literature on reported speech. And although Wierzbicka (1974) does not cite Vološinov (1973), with the Bakhtinian approach it looks beyond features like verbatimness ${ }^{10}$ in order to explain why mentioning the 'same words' matters. Wierzbicka (1974) states that these display R's performative properties. For Vološinov (1973), they allow us to hear the 'voice' (and the meaning) of the reported speaker. In the paraphrase in (3b), that the reported speaker 'wants to say it in the same way', both insights are lost. Also lost: the insight from the formalist literature that 'words' can be mentioned in multiple ways (the funny voice of the reported speaker, his/her strange lexical choice, the use of a particular syntactic frame etc.).

Goddard and Wierzbicka's (2018) definition of indirect speech, in (4), basically explicates the de re interpretation:

(4) 'someone says this about X: - - -' (Goddard and Wierzbicka 2018)

The element 'about X' almost literally translates the Latin 'about (the thing)'. Goddard and Wierzbicka (2018) attribute the observation that indirect speech (unlike direct speech) is not about how R was said to Vološinov (1973)/Bakhtin. However, as indicated in section 2.2 this property is a byproduct for Vološinov (1973), not the actual point

${ }^{10}$ I.e. the degree to which $\mathrm{R}$ is an actual, literal representation of what the reported speaker said. This has not proven an insightful variable in the analysis of reported speech, see Vandelanotte (2009, 118-30) for discussion. 
of his analysis. The de re interpretation in indirect speech is a structurally reflected expression of transferring to the voice of the current speaker ${ }^{11}$. No aspect of (3) or (4) reflects the Bakhtinian approach.

\section{The universality of the direct/indirect speech opposition and Ungarinyin reported speech}

Whereas Goddard and Wierzbicka (2018) loose explanatory power compared with Wierzbicka (1974), their account also makes a considerably stronger claim about the expression of reported speech than the earlier paper: Goddard and Wierzbicka (2018) suggest that the semantic primes involved in the definition in (3) and (4) have direct syntactic relevance. Specifically, they suggest that in the languages of the world the semantic prime SAY is necessarily expressed through a lexeme 'say' in reported speech:

'[A]Il languages have a word (a verb) encoding, in one of its meanings, the indefinable concept SAY, with a valency option which allows this word to introduce a quotation: "he/she said: - - -'; and this basic frame can be extended to include an addressee: 'he/she said to someone: - - '. Second, all languages appear to have resources for approximating other people's speech, that is, they allow the verb meaning SAY (or SPEAK) to combine with a phrase (or a word) meaning 'like this', i.e. to the frame 'he/she said/spoke like this...' (Goddard and Wierzbicka 2018)

The decision to base the analysis of reported speech on a word that (in one of its meanings) expresses the prime SAY has two important consequences: (1) it leads to the claim that all languages use a lexeme meaning SAY or SPEAK in reported speech, and (2) it suggests that direct and indirect speech as defined above are universal categories, since these correspond to the proposed syntactic frames associated with SAY or SPEAK. The main argument that Goddard and Wierzbicka (2018) put forward for this far-reaching hypothesis is that a definition of reported speech that makes use of the semantic prime SAY is clearer and simpler than definitions proposed in the literature that do not, like Spronck (2015a).

Unnecessary obscurity is an offence too often committed in academia and in crosscultural communication, and Goddard and Wierzbicka (2018) are right to call attention to this. However, the argument of simplicity cannot cover up the fact that the hypothesis that reported speech expressions necessarily involve a lexeme 'say' does not follow from the premises that SAY and SPEAK are semantic primes. It is entirely possible to accept that SAY (and THINK) are possibly universal concepts/semantic primes while rejecting the idea that reported speech constructions can and should be defined on the basis of these lexematic meanings ${ }^{12}$.

11 Again, to the extent that we can apply the binary opposition de dicto/de re at all to the Bakhtinian analysis: significantly, for Vološinov (1973) and Bakhtin (1981) in most utterances voices are 'mixed'.

12 One reason for why Goddard and Wierzbicka $(2018,2019)$ may not acknowledge the rather obvious distinction between the meaning of a construction and its lexematic content is because, especially after Wierzbicka (1996), the research programme on the Natural Semantic Metalanguage increasingly seems to assume a strong link between syntactic frames and the combinability of the presumed universal semantic building blocks of language, semantic primes (Gladkova and Larina $2018,503)$. Without taking a position on this research goal, it seems to me that it is consistent with the idea that a semantic prime (or even a combination of semantic primes) may be expressed with a specific 
A minor debate around this distinction in recent years has focused on Australian languages, such as Bunuba and languages of the Nyulunylan family, in which the distinction between SAY and THINK is underspecified in reported speech (cf. Goddard 2003, 115; Wierzbicka 1996, 197ff; Knight 2008; McGregor 2014; Goddard and Wierzbicka 2018). The original discussion of such a language is Rumsey (1990), who finds that in Ungarinyin (Australian; Worrorran) reported speech/thought constructions are inherently ambiguous, as in (5).

\begin{tabular}{|c|c|c|}
\hline [[ ngurrba & nyungiminda ] & ama jirri ] \\
\hline$[[$ ngurrba & nyunga $\left.a_{2}-i y-m i n d a\right]$ & $a_{1}-m a-\varnothing$ jirri $]$ \\
\hline [[ hit-ITRV & $3 \mathrm{fsg} . \mathrm{O}: 1 \mathrm{sg} . \mathrm{S}-\mathrm{FUT}-\mathrm{TAKE}]$ & 3msg-do-PRS m.ANAPH ] \\
\hline \multicolumn{3}{|c|}{ 'He says: "I will hit her", or: He says that he will hit her' } \\
\hline 'He thinks: " & will hit her", or: He thinks $\mathrm{t}$ & lat he will hit her' \\
\hline wants $t$ & it her' (Spronck 2015b, 71 & \\
\hline
\end{tabular}

Crucially, Rumsey (1990) does not suggest that Ungarinyin does not have dedicated lexemes for SAY or THINK (it has $n i$ 'think', and wurla 'speak' is often translated by Ungarinyin speakers as 'say'), but the syntactic construction used for expressing reported speech is not built around such lexically specific words. Rumsey (1990) also does not claim that speakers of Ungarinyin would be stumped by the conceptual distinction between holding a thought in one's head and physically uttering words (also see McGregor 2014). However, in Ungarinyin the lexemes meaning wurla 'say, speak' and $n i$ 'think' cannot be used in a syntactic reported speech construction. What examples such as (5) indicate is that Ungarinyin makes a distinction between the meanings SAY and THINK (which, as per Wierzbicka $(1996,50)$ could therefore still be semantic primes) and the syntactic structure used for reported speech (also see Spronck 2015b). On the basis of these and other observations Spronck and Nikitina (2019) argue that reported speech should be analysed as a syntactic construction in its own right, more on a par with epistemic expressions (i.e. modal and evidential structures) than regular transitive/intransitive clauses headed by a specific verb (also see Rumsey 1982; McGregor 1994; Spronck 2017).

Rumsey (1990) further states that since Ungarinyin only has a single reported speech construction, it would be a mistake to call this construction direct speech: the absence of a structural opposition between different types of reported speech means that the de dicto/de re distinction is simply not codified in Ungarinyin grammar.

Goddard and Wierzbicka (2018), as well as Goddard and Wierzbicka (2019), address none of these arguments, which is particularly troubling since there is a plausible link between legalistic/written culture and cultivation of a strict direct/indirect speech opposition (Linell 2005, 94). Whereas it has been one of the hallmarks of Anna Wierzbicka's work to identify such cultural biases in cross-linguistic meaning, for example

syntactic multi-word construction in some languages and with a specific word or combination of lexemes in others. Under this assumption, whether a reported speech construction expresses a universal meaning and whether all languages have lexemes that can express, e.g., the meaning SAY SOMETHING are two entirely different questions. 
in pointing out the non-universality of Anglo 'probably' (Wierzbicka 2006, 267-68), Goddard and Wierzbicka (2018) simply posit de dicto marking ('how $\mathrm{R}$ was said') as a universal. This is a much more sweeping claim than the account Wierzbicka (1974) puts forward, since the latter primarily sought to define English direct/indirect speech. What is more, it is an entirely unmotivated and unnecessary step for the purpose of arguing that the notion of SAY can be understood in all cultures. And it is an outright regressive step with respect to valuing cross-linguistic variation.

\section{Discussion and conclusion: Taking Vološinov and Bakhtin seriously}

If we take Vološinov (1973) seriously, there is a second reason for why refraining from defining reported speech on the basis of SAY and THINK is preferable: reported speech is an entry point to studying the grammar of Bakhtinian dialogue. For this reason, Spronck (2015a) seeks to characterise reported speech using more general grammatical meanings, such as evidentiality and modality (also see Spronck (2017), Spronck and Nikitina (2019)). I fully accept that these definitions of reported speech may be simplified and improved, and am grateful for Goddard and Wierzbicka $(2018,2019)$ to engage in debate around them. But these definitions aim to examine the Bakhtinian hypothesis that the structure of reported speech can bring us closer to understanding how dialogue shapes grammar. Given the observation that Bakhtininan ideas about addressivity are reflected in more types of grammatical structures than is commonly acknowledged in language description and typology (cf. Evans, Bergqvist, and San Roque 2018), I believe that such a research programme has value, alongside lexical approaches like Goddard and Wierzbicka (2018) espouse.

(C) Stef Spronck, 2019

cc) coative

https://creativecommons.org/licenses/by/4.0/

\section{Acknowledments}

I thank Sergeiy Sandler, Alan Rumsey, Tatiana Nikitina, the editor of this journal Tatiana Larina, Helen Bromhead and the anonymous reviewers for very helpful comments and discussion. None of them bear any responsibility for what appears here, but I am grateful for the errors they enabled me to take out.

\section{REFERENCES}

Abbott, Barbara (2011). Attitudes Toward Quotation. In Understanding Quotation, edited by Elke Brendel, Jörg Meibauer, and Markus Steinbach, 35-46. Berlin/New York: De Gruyter Mouton.

Bakhtin, Mikhail (1981). The Dialogic Imagination: Four Essays by M. M. Bakhtin. Edited by Michael Holquist. Austin: University of Texas.

Banfield, Ann (1982). Unspeakable Sentences: Narration and Representation in the Language of Fiction. Boston: Routledge \& Kegan Paul.

Bertau, Marie-Cécile (2004). Reflections on Addressivity: From the Role of the Other to Developmental Aspects. In Aspects of the Dialogical Self: Extended Proceedings of a Symposium on the Second International Conference on the Dialogical Self, edited by Marie-Cécile Bertau, 87-128. Berlin: Lehmanns. 
Bota, Cristian, and Jean-Paul Bronckart (2011). Bakhtine Démasqué: Histoire d'un Menteur, d'une Escroquerie et d'un Délire Collectif. Paris: Droz.

Burge, Tyler (2012). Referring de Re. In Having in Mind: The Philosophy of Keith Donnellan, edited by Joseph Almog and Paolo Leonardi, 107-21. Oxford etc.: Oxford University Press.

Cappelen, Herman, and Ernest Lepore (2012). Quotation. In The Stanford Encyclopedia of Philosophy (Spring 2012 Edition), edited by Edward N. Zalta. http://plato.stanford.edu/archives/spr2012/ entries/quotation/.

Capuano, Antonio (2012). The Ground Zero of Semantics. In Having in Mind: The Philosophy of Keith Donnellan, edited by Joseph Almog and Paolo Leonardi, 7-29. Oxford etc.: Oxford University Press.

Cieśluk, Andrzej (2010). De Re/de Dicto Distinctions (Syntactic, Semantic and Pragmatic Interpretation). Studies in Logic, Grammar and Rhetoric 22 (35): 81-94.

Cresswell, James, and Allison Hawn (2011). Drawing on Bakhtin and Goffman: Toward an Epistemology That Makes Lived Experience Visible. Forum Qualitative Sozialforschung / Forum: Qualitative Social Research 13 (1). <http://www.qualitative-research.net/index.php/fqs/article/ view/1594/3306> (Date accessed: 15 February 2016).

Davidson, Donald (1968). On Saying That. Synthese 19 (1): 130 - 46.

De Brabanter, Philippe (2005). Quotations and the Intrusion of Non-Linguistic Communication into Utterances. Context, 126-39.

De Brabanter, Philippe (2017). Why Quotation Is Not a Semantic Phenomenon, and Why It Calls for a Pragmatic Theory. In Semantics and Pragmatics: Drawing a Line, edited by Ilse Depraetere and Raf Salkie, 227-54. Dordrecht etc.: Springer.

Erdinast-Vulcan, Daphna, and Sergeiy Sandler (2015). Bakhtin and His Circle. In Theoretical Schools and Circles in the Twentieth-Century Humanities: Literary Theory, History, Philosophy, edited by Marina Grishakova and Silvi Salupere, 23- 40.

Evans, Nicholas, Henrik Bergqvist, and Lila San Roque (2018). The Grammar of Engagement I: Framework and Initial Exemplification. Language and Cognition, 110 - 40. https://doi.org/ 10.1017/langcog.2017.21.

Frege, Gottlob (1892). Über Sinn Und Bedeutung. Zeitschrift Für Philosophie Und Philosophische Kritik 100: 25-50.

Frege, Gottlob (1948). Sense and Reference. The Philosophical Review 57 (3): 209-30.

García-Carpintero, Manuel (2011). Double-Duty Quotation, Conventional Implicatures and What Is Said. In Understanding Quotation, edited by Elke Brendel, Jörg Meibauer, and Markus Steinbach, 107-38. Berlin/New York: De Gruyter Mouton.

Geurts, Bart, and Emar Maier (2005). Quotation in Context. Belgian Journal of Linguistics 17: $109-28$.

Gladkova, Anna, and Tatiana Larina (2018). Anna Wierzbicka, Words and the World. Russian Journal of Linguistics 22 (3): 499-520. https://doi.org/10.22363/2312-9182-2018-22-3-499-520.

Goddard, Cliff (2003). Thinking Across Languages and Cultures: Six Dimensions of Variation. Cognitive Linguistics 14 (2-3): 109-40. http://www.degruyter.com/view/j/cogl.2003.14.issue2-3/cogl.2003.005/cogl.2003.005.xml.

Goddard, Cliff, and Anna Wierzbicka (2018). Direct and Indirect Speech Revisited: Semantic Universals and Semantic Diversity. In Capone, Alessandro et al. (eds) Perspectives in Pragmatics, Philosophy \& Psychology, 173 — 99. Springer. https://doi.org/10.1007/978-3-319-78771-8_9.

Goddard, Cliff, and Anna Wierzbicka (2019). Reported Speech as a Pivotal Human Phenomenon: Commentary on Spronck and Nikitina. Linguistic Typology 23 (1): 167-75. https://doi.org/ 10.1515/lingty-2019-0006. 
Goddard, and Routley (1966). Use, Mention and Quotation. Australasian Journal of Philosophy 44: 1 .

Goffman, Erving (1979). Footing. Semiotica 25 (1-2): 1-30.

Goffman, Erving (1981). Forms of Talk. Philadelphia: University of Pennsylvania Press.

Goodwin, Charles (2007). Interactive Footing. In Reporting Talk: Reported Speech in Interaction, edited by Elizabeth Holt and Rebecca Clift, 16-46. Cambridge etc.: Cambridge University Press.

Gutzmann, Daniel, and Erik Stei (2011). Quotation Marks and Kinds of Meaning. Arguments in Favor of a Pragmatic Account. In Understanding Quotation, edited by Elke Brendel, Jörg Meibauer, and Markus Steinbach. Berlin/New York: De Gruyter Mouton.

Güldemann, Tom (2008). Quotative Indexes in African Languages: A Synchronic and Diachronic Survey. Berlin: Mouton de Gruyter.

Holquist, Michael (2002). Dialogism. Bakhtin and His World. 2nd edition. London/New York: Routledge.

Jacquette, Dale (2017). Referential Analysis of Quotation. In The Semantics and Pragmatics of Quotation, edited by Paul Saka and Michael Johnson, 335-55. Springer International Publishing.

Knight, Emily (2008). Hyperpolysemy in Bunuba, a Polysynthetic Language of the Kimberley, Western Australia. In Cross-Linguistic Semantics, edited by Cliff Goddard, 205-23. Amsterdam/ Philadelphia: John Benjamins.

Kuipers, Joel (2013). Evidence and Authority in Ethnographic and Linguistic Perspective. Annual Review of Anthropology 42: 399 - 413.

Lähteenmäki, Mika (2001). Dialogue, Language and Meaning: Variations on Bakhtinian Themes. $\mathrm{PhD}$ thesis, University of Jyväskylä.

Linell, Per (2005). The Written Language Bias in Linguistics: Its Nature Origins and Transformations. London; New York: Routledge.

Maier, Emar (2007). Mixed Quotation: Between Use and Mention. In Proceedings of Lenls 2007.

McGregor, William B. (1994). The Grammar of Reported Speech and Thought in Gooniyandi. Australian Journal of Linguistics 14 (1): 63-92.

McGregor, William B. (2014). The 'Say, Do' Verb in Nyulnyul, Warrwa, and Other Nyulnylan Languages Is Monosemic. In Events, Arguments and Aspects: Topics in the Semantics of Verbs, edited by Klaus Robering, 301-27. Amsterdam/Philadelphia: John Benjamins.

Quine, W.V. (1956). Quantifiers and Propositional Attitudes. The Journal of Philosophy 53 (5): 177-87. https://doi.org/10.2307/2022451.

Recanati, François (2001). Open Quotation. Mind 110 (439): 637-87.

Recanati, François (2008). Open Quotation Revisited. Philosophical Perspectives 22: 443-71.

Rumsey, Alan (1982). An Intra-Sentence Grammar of Ungarinjin, North-Western Australia. Canberra: Pacific Linguistics.

Rumsey, Alan (1990). Wording, Meaning and Linguistic Ideology. American Anthropologist 92 (2): $346-61$.

Saka, Paul (1998). Quotation and the Use-Mention Distinction. Mind 107 (425): 113-35. https://doi.org/10.1093/mind/107.425.113.

Saka, Paul (2006). The Demonstrative and Identity Theories of Quotation. The Journal of Philosophy 103 (9): 452-71.

Sandler, Sergeiy (2013). Language and Philosophical Anthropology in the Work of Mikhail Bakhtin and the Bakhtin Circle. Rivista Italiana Di Filosofia Del Linguaggio, no. 2: 152-65. https://doi.org/10.4396/20130711. 
Sandler, Sergeiy (2016). Fictive Interaction and the Nature of Linguistic Meaning. In The Conversation Frame: Forms and Functions of Fictive Interaction, edited by Esther Pascual and Sergeiy Sandler. Amsterdam/Philadelphia: John Benjamins.

Spronck, Stef (2015a). Refracting Views: How to Construct Complex Perspective in Reported Speech and Thought in Ungarinyin. STUF - Language Typology and Universals 68 (2): 165-85.

Spronck, Stef (2015b). Reported Speech in Ungarinyin: Grammar and Social Cognition in a Language of the Kimberley Region, Western Australia. PhD thesis, The Australian National University. http://hdl.handle.net/1885/733712596.

Spronck, Stef (2017). Defenestration: Deconstructing the Frame-in Relation in Ungarinyin. Journal of Pragmatics 114: 104-33. https://doi.org/https://doi.org/10.1016/j.pragma.2017.03.016.

Spronck, Stef, and Tatiana Nikitina (2019). Reported Speech Forms a Dedicated Syntactic Domain. Linguistic Typology 23 (1): 119-59.

Vandelanotte, Lieven (2009). Speech and Thought Representation in English: A Cognitive-Functional Approach. Berlin/New York: De Gruyter Mouton.

Vološinov, Valentin N. (1972). Marksizm I Filosofija Jazyka. The Hague/Paris: Mouton. (Facsimile reprint of the second edition, originally published by Priboj, Leningrad, 1930.)

Vološinov, Valentin N. (1973). Marxism and the Philosophy of Language. Edited by Ladislav Matejka and I. R. Titunik. New York/London: Seminar Press.

Wierzbicka, Anna (1974). The Function of Direct and Indirect Discourse. Papers in Linguistics 7 (3): $267-307$.

Wierzbicka, Anna (1996). Semantics, Primes and Universals. Oxford etc.: Oxford University Press.

Wierzbicka, Anna (2006). English: Meaning and Culture. Oxford etc.: Oxford University Press.

\section{Article history:}

Received: 19 February 2019

Revised: 08 April 2019

Accepted: 10 May 2019

\section{История статьи:}

Дата поступления в редакцию: 19 февраля 2019

Дата принятия к печати: 10 мая 2019

\section{Bionote:}

STEF SPRONCK ( $\mathrm{PhD}$ The Australian National University 2016) is a postdoctoral researcher at the University of Helsinki, Finland, and previously at the University of Leuven, Belgium. After his training in Slavic and General Linguistics at the University of Amsterdam, The Netherlands, he carried out extensive documentary fieldwork in Aboriginal Australia, working on reported speech and stance in Ungarinyin. His research focuses on typology, dialogic linguistics and reported speech/TAME.

Contact information: e-mail: stef.spronck@helsinki.fi

\section{Сведения об авторе:}

СТЕФ СПРОНК получил степень $\mathrm{PhD}$ в Австралийском национальном университете (2016), научный сотрудник Хельсинского университета (Финляндия), до этого - Лёвенского университета (Бельгия). После обучения по программе славянского и общего языкознания в Амстердамском университете (Нидерланды) провел обширное полевое исследование языков аборигенов Австралии, в частности косвенной речи и картины мира аборигенов Ungarinyin. Сфера научных интересов: типология, диалогическая лингвистика, чужая речь.

Контактная информация: e-mail: stef.spronck@helsinki.fi 